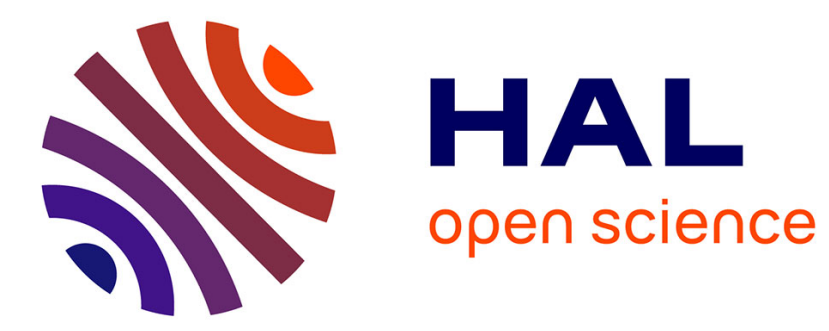

\title{
The growing importance of diversification activities for French farm households
}

\author{
Catherine C. Benjamin
}

\section{To cite this version:}

Catherine C. Benjamin. The growing importance of diversification activities for French farm households. 35. Seminar: Rural realities: trends and choices, Jun 1994, Aberdeen, United Kingdom. hal-02847751

\section{HAL Id: hal-02847751 \\ https://hal.inrae.fr/hal-02847751}

Submitted on 7 Jun 2020

HAL is a multi-disciplinary open access archive for the deposit and dissemination of scientific research documents, whether they are published or not. The documents may come from teaching and research institutions in France or abroad, or from public or private research centers.
L'archive ouverte pluridisciplinaire HAL, est destinée au dépôt et à la diffusion de documents scientifiques de niveau recherche, publiés ou non, émanant des établissements d'enseignement et de recherche français ou étrangers, des laboratoires publics ou privés.

\section{다(1) $\$$}

Distributed under a Creative Commons Attribution - NonCommercial| 4.0 International 


\title{
The Growing Importance of Diversification Activities
}

\section{for French Farm Households}

by

\author{
C. Benjamin
}

Institut National de la Recherche Agronomique

Station d'Economie et Sociologie rurales de Rennes

Unite Politique Agricole et Modélisation

65, rue de St-Brieuc - 35042 Rennes cedex - France

E-mail: cbenjami@roazhon.inra.fr - fax. (33) 99.28.53.80

\begin{abstract}
Diversification activities, on-farm or off-farm, can allow farmers not to rely exclusively on farming for the household's income. In many rural areas, on-farm tourism and off-farm employment have became an important and steady source of income for farm households. The most significant change over the last ten years has been the substantial growth in off-farm labour participation by farm spouses. This paper based on the neoclassical farm-household is an attempt to characterize the variables that affect the decisions to work off-farm for the French farm households and the decision whether or not to hire labour on farm. Furthermore the impact of the Common Agricultural Policy (CAP) on the participation in the off-labour market is studied. In a simplified model where male and female labour are perfect substitutes we can show that the reduction in the cereals price and the set-aside would induce a decrease in the reservation wage and hence an increase in the probability of off-farm participation. On the other hand the receipt of compensatory payment would have a negative impact on the probability of off-farm work participation. Empirical results show that while the CAP reform will increase wives' off-farm participation, education and age have a greater positive effect. Furthermore, simulations show that the impact of the CAP reform on off-farm labour market participation is higher for wives who do not have a high school diploma than for those who do.
\end{abstract}




\section{Introduction}

The growing importance of diversification activities for farm households has been identified as a new feature of Western agriculture. Diversification activities, on farm or off farm, can allow farmers not to rely exclusively on farming for the household's income. Indeed, in many rural areas, on-farm tourism and off-farm employment have became an important and steady source of income for farm households. In France, nonagricultural income represents an increasing percentage of farm household income: rising from $15 \%$ in 1956 to more than $42 \%$ in 1988 . Several factors have contributed to this increase. The number of farms involved in tourism activities has increased by roughly $20 \%$ since 1978 , although only a fraction of farms are engaging in tourism activity. The most significant change over the last ten years has been the substantial growth in off-farm labour participation by farm spouses: the percentage of young wives under 35 years old working off farm rose from $26 \%$ in 1979 to $52 \%$ in 1988 . The prevalence and magnitude of off-farm employment income in European countries have been described which are, to our knowledge, mainly descriptive (Gasson, 1988; The Arkleton Trust, 1991). Empirical studies of off-farm work participation choices have been, in most cases, applied to American and Canadian agriculture (Lass et al. 1991; Huffman et Lange 1989).

Growth in part-time farming and in diversification of agricultural activities may be affected by the 1992 Common Agricultural Reform (CAP) reform. This recent shift in support policy implies a major change in the nature of support provided to the cereals sector. This consists of support price cuts and a mandatory acreage set-aside in return for compensatory payments. We might expect that this reform would affect off-farm labour decisions of French agricultural households. To date, research on off-farm labour supply did not provide information on the reactions of farm households to changing economic conditions, such as output price variations (Lass et al.). The purposes of this paper are i) to identify the factors that lead French farmers to supply off-farm labour ii) to find out how the changes in the nature of support given to the European agricultural sector will affect the off-farm labour decisions and iii) to quantify the impacts of the variations of output price, land used, and the amount of subsidies on the probability of off-farm work for French grain farmers.

Our first step is to present a model of household behaviour to identify the variables that affect the labour decisions. The neo-classical firm-household model Nakajima (1969) emphasizes the interdependence between the firm's profit maximisation and household's utility maximisation behaviour. Previous studies have modelled within this framework off-farm work decisions of 
farm operators and their spouses (see Hallberg et al. 1991 for a recent survey). Our analysis is along the same lines but differs in that it explicitly includes hired labour decision as a decision variable. The decision of the household to work off farm and the decision to use hire labour on the farm are joint and our model takes into account their simultaneity. The farm household model allows us to characterize a rule for off-farm work participation: the household defined as an entity, will not work off farm when its marginal value of time from not participating in the offfarm labour market (its reservation wage) is greater than the wage rate offered off-farm. Furthermore, the household will use hired labour when the marginal value of hired labour equals its cost. The comparative static of the reservation wage and the marginal value of hired labour with respect to the instruments used in the new CAP regime allow the formation of hypotheses regarding how CAP will affect labour decisions.

The plan of the paper as is follows. Section 2 details the analytical model. In the third section, the theoretical model is applied to a sample of 1518 grain farms. In the empirical analysis we attempt to characterize the variables which affect the decisions to work off-farm for the French farm households and the decision whether or not to hire labour on farm. In section 4 our attention is directed to the quantitative impact of the CAP reform on the probability of off-farm work. Finally, we conclude with some observations regarding policy analysis and further research in this area.

\section{The theoretical framework}

\subsection{A simplified model}

The farm household is defined as an economic entity ${ }^{1}$ and is assumed to maximise its utility function subject to income, time and non-negativity constraints :

$$
\max _{L F, L D, C, L H} U(L F, L O, C ; E, A)
$$

subject to

$$
\begin{aligned}
& p_{C} C \leq \pi(p, v, L F, L H, Z ; E, D)+w_{o} L O+B-w L H \\
& L F+L O+L E I \leq T \\
& L F \geq 0
\end{aligned}
$$

\footnotetext{
1 We assume that male and female family labour are perfect substitutes.
} 


$$
\begin{aligned}
& L O \geq 0 \\
& C \geq 0 \\
& L H \geq 0
\end{aligned}
$$

The utility function $(U()$.$) depends on on-farm family labour (L F)$, on off-farm family labour $(L O)$, and on the vector of consumption goods $(C)$. The utility function depends also on human capital variables $(E)$ and on household characteristics $(A)$. The associated price of consumption goods is $\left(p_{C}\right)$. The restricted conditional profit function is denoted $\pi$. It depends on the product price vector $(p)$, the price vector of variable input $(v)$, on-farm family work, hired labour level $L H$, fixed factors $(Z)$, human capital variables and other exogenous shifters of supply $(D)$. The wage rate for hired labour is noted $w$. Other variables used include the off-farm wage rate $\left(w_{o}\right)^{2}$, exogenous household income (B), leisure time of the household (LEI) and total time available to the household $(T)$.

The utility function is well-defined and continuous from above, quasi-concave in $L F, L O$ and $C$, nonincreasing in $L F$ and $L O$ and nondecreasing in $C$ (Diewert, 1974). The restricted profit function is nonnegative, linearly homogeneous, continuous and convex in prices, nondecreasing, continuous and concave in quantities (Lopez, 1984). Furthermore, on-farm and off-farm family labour are assumed to be perfect substitutes in the utility function as well as family labour and hired labour in the production function despite their differential opportunity costs.

Constraint [1.a] is the budget constraint : the value of consumption must be lower than or equal to total income $(M)$ which is defined as the sum of farm profits, off-farm wage and exogenous income. Constraint [1.b] is the time constraint: the household can allocate his available time to on-farm work, off-farm work and to leisure. Constraints [1.c] to [1.f] are positivity constraints. We suppose that the budget and the time constraints are bounded. Furthermore, the price of the consumption good is used as the numeraire.

Assuming interior solutions for on-farm family labour and for the consumption, the associated Kuhn-Tucker conditions for a maximum are:

$$
-(\partial U / \partial L F) /(\partial U / \partial M)=\partial \pi / \partial L F
$$

\footnotetext{
2 This off-farm wage rate is assumed to be independent from hours worked but to be a function of human capital variables and location parameters.
} 


$$
\begin{aligned}
& -(\partial U / \partial L O) /(\partial U / \partial M)-\tau /(\partial U / \partial M)=w_{o} \\
& \partial \pi / \partial L H=w-\mu /(\partial U / \partial M)
\end{aligned}
$$

where $\tau$ and $\mu$ are the Lagrangean multipliers associated with the non-negativity constraint [1.d] on off-farm family labour and the non-negativity constraint [1.f] on hired labour.

Equation [2] states that the marginal rate of substitution between on-farm family labour and income is equal to the marginal value of farm labour. Equation [3] provides the criterion for off-farm participation. Off-farm work will be zero if the marginal rate of substitution between off-farm family labour and income is greater than the off-farm wage rate. An interior solution occurs for off-farm family labour when the marginal rate of substitution is equal to the off-farm wage rate. Equation [4] defines the criterion for employing hired labour on farm. Hired labour is used on farm when its marginal value product is equal to its price.

Hence, the participation rule for the off-farm labour market for the household is defined as

$$
\begin{aligned}
& L O>0 \text { if } \quad w_{o}>-(\partial U / \partial L O / \partial U / \partial M)_{L O=0} \\
& L O=0 \quad \text { if } \quad w_{o} \leq-(\partial U / \partial L O / \partial U / \partial M)_{\mid L O=0}
\end{aligned}
$$

Since on-farm work and off-farm work are perfect substitutes we can rewrite the participation rule for the off-farm labour market as:

$$
\begin{aligned}
& L O>0 \text { if } w_{o}>\partial \pi / \partial L F_{\mid L O=0} \\
& L O=0 \quad \text { if } \quad w_{o} \leq \partial \pi / \partial L F_{\mid L O=0}
\end{aligned}
$$

The right-hand side of these inequalities gives the marginal value of time when the household allocates all of its work time to on-farm labour, i.e. it defines the reservation wage. The criterion of participation in the off-farm labour market is based on a comparison of the offfarm wage rate and the reservation wage. Factors which influence the reservation wage and the off-farm wage rate will affect the criterion of participation. For instance, variables that raise (or decrease) the off-farm wage rate increase (or decrease) the probability of off-farm work while variables that raise (or decrease) the reservation wage rate decrease (or increase) the probability of off-farm work.

Along the same lines, the rule for using hired labour on farm is defined as:

$$
L H>0 \quad \text { if } \quad \partial \pi / \partial L H_{\mid L H=0}>w
$$




$$
L H=0 \quad \text { if } \quad \partial \pi / \partial L H_{\mid L H=0} \leq w
$$

The left-hand side of these inequalities defines «the reservation wage of hired labour». Variables that raise (or decrease) this value increase (or decrease) the probability of using hired labour.

Both labour decisions rules [7] and [8] are likely to be affected with the CAP reform through the variations in exogenous variables implied by the reform.

\subsection{Effect of the CAP reform on the participation in the off-farm labour market}

The new CAP regime marks a major change in the nature of support given to EC cereal farmers. Central to the reform is a phased reduction in institutional prices for cereals. To offset the income effects of the reduction in support prices, farmers will receive compensation payments if they comply with set-aside requirements (they have to set aside $15 \%$ of the base area ${ }^{3}$ ). This reform will induce variations in output price, in land area and in exogenous income.

By assumption, the off-farm wage rate depends only on the human capital variables and on the location parameters. It is not affected by the CAP reform. On the other hand, the reservation wage is a function of exogenous shifters of supply and demand: output and input prices, fixed assets, other factors that shift the production level, human capital variables, household characteristics, exogenous income and local labour market variables. The reform will affect the household's reservation wage and therefore the participation rule in the off-farm labour market. The total effect of the CAP reform on the reservation wage can be written as

$$
d w_{r}=\partial w_{r} / \partial p d p+\partial w_{r} / \partial Z d Z+\partial w_{r} / \partial B d B
$$

where $w_{r}$ is the household's reservation wage

We have to consider the comparative static of the household's reservation wage with respect to product price, to land area and to non labour income. We can prove that $\partial w_{r} / \partial p>0$, $\partial w_{r} / \partial Z>0$ and $\partial w_{r} / \partial B>0{ }^{4}$. It follows that the reduction in cereals price and the set-aside of land would induce a decrease in the reservation wage of the members of the household, hence an increase in the probability of off-farm participation. On the other hand, the receipt of the compensatory payment for reduced price support would have a negative impact on the probability

\footnotetext{
3 Small producers (i.e. those who have an insufficient land area to produce 92 tonnes of cereal at reference yields) are exempt from this requirement.

4 Formal analysis of these cases and the comparative static results presented in this paper are outlined in Benjamin, 1993.
} 
of off-farm participation. Hence, the total effect on the reservation wage is indeterminate because there are opposite effects. However, under the compensation payments planned in the new CAP regime we can predict the sign of the total effect.

The sign of the effect on the reservation wage depends eventually on the farm yield. Indeed, when the individual yield is greater than or equal to the reference yield ${ }^{5}$, the total effect on the reservation wage is negative. As a conclusion we expect that the effect of a decrease in product price, set-aside and receipt of compensatory payments will induce a decrease in the reservation wage and hence an increase in the probability of off-farm participation.

\section{Empirical results}

We turn to French data to characterize the variables which affect the variations of the probability of off-farm participation and of the probability of using hired labour. In the empirical analysis, we distinguish the wife's behaviour from the husband's behaviour because both spouses might be not influenced by the same factors.

The theoretical model developed in section two is applied to a sample of French field crops farms. Two considerations explain this choice: i) the importance of the off-farm participation labour rate in this specialisation and ii) the focus of the CAP reform on the cereals sector. We, first, define the econometric specification. Next, we present the data base. Finally, the empirical results are discussed.

\subsection{Econometric specification}

The empirical model includes three participation decision rules based on the comparison of the reservation wage and the corresponding market wage. The model for estimating off-farm participation and hired labour use probabilities may be written as:

$$
\begin{aligned}
& w_{i r}=X_{i} \beta_{i}+\mu_{i} \quad \mathrm{i}=\mathrm{f}, \mathrm{h} \\
& \partial \pi / \partial L H_{\mid L H=0}=Y^{\prime} \alpha+\varepsilon
\end{aligned}
$$

where $\mathrm{f}$ and $\mathrm{m}$ represent female and male respectively. $X_{i}$ and $\mathrm{Y}$ define the vectors of exogenous variables, $\beta_{i}$ and $\alpha$ are the parameters to estimate and $\varepsilon$ and $\mu_{i}$ are stochastic errors.

\footnotetext{
5 A reference yield is used to calculate the rate of compensation per hectare.
} 
We define three binary variables, $D_{i}(\mathrm{i}=\mathrm{f}, \mathrm{h})$ which equals one if the individual $\mathrm{i}$ (the farmer or his wife) works off-farm and zero otherwise, $D_{L H}$ which equals one if the farm uses hired labour and zero otherwise. The decision rules are finally expressed in terms of observable exogenous variables, unknown parameters and stochastic error terms.

$$
\begin{aligned}
\operatorname{Pr} o b\left(L O^{i}\right. & >0)=\operatorname{Pr} o b\left(D_{i}=1\right)=\operatorname{Pr} o b\left(w_{r i}<w_{o}^{i}\right) \\
& =\operatorname{Pr} o b\left(\mu_{i}<w_{o}^{i}-\beta_{i} X_{i}\right) \\
\operatorname{Prob}(L H & >0)=\operatorname{Prob}\left(D_{L H}=1\right)=\operatorname{Prob}(\partial \pi / \partial L H<w) \\
& =\operatorname{Prob}(\varepsilon<w-\alpha Y)
\end{aligned}
$$

Since the participation decisions of the husband and the wife in off-farm work and the decision for hiring labour on farm are simultaneous, a joint estimation procedure should increase the statistical efficiency of the parameter estimates. Assuming that stochastic errors have a normal distribution, the appropriate statistical model is the multinomial probit model. Unfortunately, there does not exist analytical solution in that case and the multinomial probit model must be solved by numerical methods which are difficult to implement. Consequently a simplified procedure has been preferred, three univariate probit models are estimated.

\subsection{Data}

The model is estimated using a random sample of French farm households drawn from the 1988 General Census of French Agriculture. A total of 1518 households were retained after eliminating observations with missing data and the farmers who did not grow grain crops. In that subsample, 331 wives (about $24 \%$ ) report off farm activities, 157 husbands (about $10 \%$ ) work off farm and 574 farms (about 38\%) use hired labour.

Four classes of variables have been distinguished corresponding to: i) individual characteristics, ii) family characteristics, iii) farm characteristics and iv) location characteristics.

Individual characteristics are age and several variables measuring human capital: general education, agricultural education, agricultural training courses and agricultural work experience. A dummy variable represents the general education level of each individual (equal to 1 if the individual attained the baccalaureat or more, 0 otherwise). Agricultural education is likewise represented by a dummy variable set to 1 if the individual has an agricultural high school diploma, 0 otherwise. Finally, participation in recent agricultural courses is defined by a dummy variable. Household characteristics include: the number of children under 6, between six and twelve, child older than 12 and the total number of family members living on-farm. Farm 
characteristics include: the farm size and dummy variables which describe farms involved in farm tourism, farms taking on-farm diversification activities (which include mainly on-farm agricultural products sales), farms benefiting from a development plan and farms using a computer and a tractor of more than $80 \mathrm{HP}$. A last dummy variable describes the status of the farm (which equals 1 if the farm is a G.A.E.C. ${ }^{6}$ ). Location characteristics are defined by the average condition in the French department where the farm is located. It includes the population density of the department. Labour market conditions are measured for females (for males) by the proportion of farmers' wives (farmers) who work off-farm in the department. These regional characteristics might show opportunities to work off-farm. Data definitions with means and units of measurement are provided in Annex 1.

\subsection{Participation equations}

Results of the estimation are presented in tables 1 and 2.

6 G.A.E.C. is a form of partnership arrangement, in these farms farmers organise their business as companies and receive a salary for their work. 
Table 1. Probit analysis of the wives' off-farm labour market participation

\begin{tabular}{|c|c|c|c|}
\hline Independent variables & Coefficients & t-student & Partial derivative \\
\hline Intercept & -1.291 & -1.53 & \\
\hline \multicolumn{4}{|l|}{ Human capital } \\
\hline Agef & 0.115 & 2.97 & -0.0094 \\
\hline Agef*agef & -0.0017 & -3.86 & \\
\hline Dumeducf & 0.801 & 7.07 & 0.17 \\
\hline Dumeduch & 0.078 & 0.49 & 0.0167 \\
\hline Dumagrf & -0.114 & -0.31 & -0.0241 \\
\hline Dumagrh & 0.059 & 0.38 & 0.0126 \\
\hline Exp & -0.036 & -5.36 & -0.0357 \\
\hline Dumpermf & -0.652 & -3.62 & -0.1389 \\
\hline Dumpermh & 0.189 & 1.59 & 0.0402 \\
\hline \multicolumn{4}{|l|}{ Household characteristics } \\
\hline Less6 & -0.17 & -1.67 & -0.0361 \\
\hline Kids612 & -0.136 & -1.75 & -0.0361 \\
\hline Old 12 & -0.081 & -1.24 & -0.0172 \\
\hline Nbind & -0.061 & -1.36 & -0.0129 \\
\hline \multicolumn{4}{|l|}{ Farm characteristics } \\
\hline Size & -0.003 & -3.33 & $*-0.0515$ \\
\hline Price & -0.004 & -1.77 & * -0.1027 \\
\hline Dumgaec & 0.441 & 2.58 & 0.0935 \\
\hline Dummicro & -0.088 & -0.66 & -0.0186 \\
\hline Dumdivers & -0.254 & -2.28 & -0.0539 \\
\hline Dumtourism & 0.68 & 2.11 & 0.1444 \\
\hline Dumdev & -0.034 & -0.25 & -0.0072 \\
\hline Dumtract & -0.01 & -0.66 & -0.0022 \\
\hline \multicolumn{4}{|l|}{ Exogenous income } \\
\hline Subven & $-1.00 \mathrm{E}-05$ & -1.46 & $*-0.0167$ \\
\hline \multicolumn{4}{|l|}{ Location characteristics } \\
\hline Density & -0.001 & -2.49 & $* \quad-0.124$ \\
\hline Averoff & 3.065 & 4.07 & * 0.1248 \\
\hline
\end{tabular}

* For the continuous variable the figure indicates the value of the quasi-elasticity i.e. the percentage change of the probability upon a one percent increase of the variable considered. At the values used to compute the derivatives and the quasi-elasticities the wife's probability of off-farm participation equals $13.07 \%$.

For each explanatory variable we calculate the partial derivative. They are evaluated at the continuous variables' sample mean and the zero value for the dummy variable. For the price variable, we assume that the product price is equal to one hundred and ten francs per quintal (the average in the grain farms' sample). Each derivative gives the increase in the probability of being an off-farm worker for an unit increase in the variable's the sample mean. 
Table 2. Probit analysis of the husbands' off-farm labour market participation

\begin{tabular}{|l|l|l|l|}
\hline Independent variables & Coefficients & t-student & Partial derivative \\
\hline Intercept & -3.962 & -3.27 & \\
Human capital & 0.1737 & 3.44 & 0.0406 \\
Ageh & -0.0019 & -3.76 & \\
Ageh*ageh & 0.199 & 1.26 & 0.0533 \\
Dumeducf & 0.51 & 2.61 & 0.117 \\
Dumeduch & -0.505 & -0.85 & -0.1085 \\
Dumagrf & -0.215 & -0.86 & -0.058 \\
Dumagrh & -0.035 & -4.4 & -0.0082 \\
Exp & 0.262 & 1.07 & 0.0604 \\
Dumpermf & -0.494 & -2.6 & -0.1218 \\
Dumpermh & -0.165 & -0.97 & \\
Household characteristics & -0.076 & -0.69 & -0.0386 \\
Less6 & 0.044 & 0.57 & -0.0178 \\
Kids612 & -0.022 & -0.45 & 0.0102 \\
Old12 & -0.008 & -3.87 & -0.005 \\
Nbind & 0.004 & 1.50 & $*-0.1458$ \\
Farm characteristics & 0.287 & 1.29 & $* 0.0963$ \\
Size & -0.062 & -0.38 & 0.067 \\
Price & -0.129 & -1.01 & -0.0144 \\
Dumgaec & 1.093 & 3.19 & -0.03 \\
Dummicro & -0.395 & -1.69 & 0.2553 \\
Dumdivers & -0.488 & -3.46 & -0.0922 \\
Dumtourism & $-3.00 \mathrm{E}-05$ & -2.12 & -0.1139 \\
Dumdev & -0.0003 & -0.62 & \\
Dumtract & 4.072 & 5.54 & -0.0507 \\
Exogenous income & & \\
Subven & & \\
Location characteristics & & -0.0087 \\
Density & & 0.9510 \\
Averoff & & \\
\hline
\end{tabular}

* For the continuous variable the figure indicates the value of the quasi-elasticity i.e. the percentage change of the probability upon a one percent increase of the variable considered. At the values used to compute the derivatives and the quasi-elasticities the husband's probability of off-farm participation equals $15.04 \%$.

For husbands and wives, the probability of off-farm participation is affected significantly by age. The life-cycle effect is quadratic. At young ages the probability of participation increases and then decreases for older ages. The maximum positive effect of age occurs at 34 years old for the wives (at 54 years old for the males), it becomes negative at 67 for the wives (at 108 years old (!) for the males). In both cases, the level of general education has a positive impact on participation decision. For the wives, the effect is stronger, the marginal effect of having an high school diploma is equal to 0.17 (for the males the effect is equal to 0.12 ). However, the individual who has more agricultural schooling has a lower probability of wage work but the effect is not significant in each equation. Greater farming experience of the farm operator has a negative effect 
on the individual's participation. An additional year of farming experience decreases the probability of working off farm by around 0.04 for the wives (by around 0.01 for the husbands). Finally the probability of participation is reduced significantly for wives and husbands who have participated in agricultural training since 1980.

The probability of the wife's off-farm participation decreases with the number of children regardless the children's age. But the effect of children on the wife's probability of participation decreases with children's age. The probability of the husband's off-farm participation does not depend on family characteristics.

Farm size has a negative and significant effect on wives' and husbands' off-farm labour participation. The effect is stronger for the husbands. A decrease of $10 \%$ in farm size increases the probability of the husband's off-farm labour participation by $1.17 \%$. For the wives, the probability of off-farm participation is affected significantly by the price. The product price has a negative and significant effect on the probability of off-farm work participation. The probability of off-farm labour participation goes up by $1.03 \%$ when the product price decreases by $10 \%$, other things being equal. For the husbands, the price effect is positive but is not significant. The probability of the wife's participation in the off-farm labour market increases significantly when the farm is in partnership. Thus, when the farm is a G.A.E.C. this probability increases by 0.09 . However, this variable has no significant effect on the husband's behaviour. Other dummy variables which characterize the equipment of the farm (benefit of a development plan, use of a micro-computer) decrease the probability of off-farm labour by wives and husbands participation but these effects are not significant. On-farm tourism activities have a positive and significant effect on the wife's participation and the husband's participation in off-farm labour. The effect is stronger for males. This effect can look somewhat puzzling. We might expect an opposite sign of this variable. In fact, this impact can be explained as follows. On farm tourism activities are parttime or seasonal activities. The existence reveals a need of another source of income than farm income. On the other hand, diversification activities which can take place all the year have a negative effect on the wife's participation. It is worth noting that this variable is not significant for the husband. This result suggests that these activities are realized by the wives. Hence, diversification activities and off-farm labour may be substitutes i.e. alternative means to diversify household income.

Subsidies have a negative and significant effect on off-farm labour participation for both individuals. The effect is four times as strong for the husbands as for the wives. An increase of $10 \%$ in subsidies decreases the husbands' probability of off-farm participation by $0.50 \%$. 
Regional variables reflect differences in off-farm employment opportunities. The effect of the density is somewhat puzzling. An increase in population density has a negative impact on the wife's participation in off-farm labour. In fact, we expected a positive effect since a high population could induce better off-farm employment opportunities. On the other hand, the proportion of wives (husbands) who are working off-farm has a positive and significant effect on the wife's (husband's) participation in off-farm labour market.

\subsection{Hired labour probit equation}

Table 3 presents the estimation of the probability of employing hired labour on farm.

Table 3. Probit analysis of the use of hired labour

\begin{tabular}{|l|l|l|l|}
\hline Independent variables & Coefficients & t-student & partial derivative \\
\hline Intercept & -1.714 & -2.79 & \\
Human capital & 0.031 & 1.26 & 0.0013 \\
Agef & -0.00029 & -1.17 & \\
Agef*agef & 0.28 & 2.61 & 0.0988 \\
Dumeducf & 0.012 & 0.08 & 0.0041 \\
Dumeduch & -0.105 & -0.3 & -0.0371 \\
Dumagrf & 0.226 & 1.55 & 0.0796 \\
Dumagrh & 0.007 & 1.29 & 0.0024 \\
Exp & -0.00008 & -0.01 & -0.0001 \\
Dumpermf & 0.236 & 2.15 & 0.0833 \\
Dumpermh & & & \\
Household characteristics & 0.155 & 3.67 & 0.0361 \\
Less6 & 0.256 & 1.59 & 0.0289 \\
Kids612 & 0.129 & 3.67 & 0.0172 \\
Old12 & -0.086 & 2.44 & -0.0129 \\
Nbind & & & \\
Farm characteristics & 0.007 & 8.4 & $* 0.1991$ \\
Size & -0.003 & -1.33 & $*-0.1028$ \\
Price & -0.026 & -0.17 & -0.0936 \\
Dumgaec & 0.209 & 1.84 & 0.0186 \\
Dummicro & 0.216 & 2.52 & 0.054 \\
Dumdivers & 0.292 & 1.04 & 0.1444 \\
Dumtourism & -0.002 & -0.02 & -0.0072 \\
Dumdev & -0.109 & -1.19 & -0.0022 \\
Dumtract & & \\
Exogenous income & $1.50 \mathrm{E}-05$ & 2.38 & $*-0.0371$ \\
Subven & & \\
\hline
\end{tabular}

* For the continuous variable the figure indicates the value of the quasi-elasticity i.e. the percentage change of the probability upon a one percent increase of the variable considered. At the values used to compute the derivatives and the quasi-elasticities the probability of hiring labour equals $31.06 \%$.

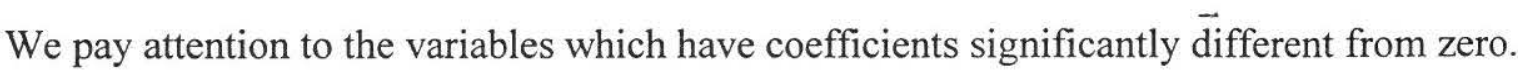


Among the human capital variables, the woman's general education has a positive impact on the probability of hiring labour. The marginal effect of achieving formal education is equal to 0.098 . This variable has the strongest positive effect of the probability of the wife working offfarm this result among the human capital and household characteristics. This result suggests that hired labour is a substitute for the woman's labour (for the women who have a general education level).

The husband's participation in recent agricultural courses increases the probability of using hired labour by 0.083 . This result indicates that hired labour is a complement for the farm labour of the man.

The presence of children increases the probability of using hired labour on farm. The effect is stronger for the number of young children. An additional year of one child under 6 increases the probability of using hired labour by around 0.09 . This effect can be explained by the substitution of hired labour for female farm labour because of child care. The number of family members living on farm has a negative effect on the probability of hiring labour.

Farm size has a positive effect on the probability of hiring labour on farm. The effect is stronger for the husbands: a decrease of $10 \%$ in farm size decreases the probability of hiring labour by $1.99 \%$. If the farm is engaged in tourism or diversification activities the probability of hiring labour increases. This result is due to labour needs on farm.

Subsidies have a positive effect: an increase of $10 \%$ in the subsidies increases the probability by $0.37 \%$.

\section{Sensitivity analysis of off-farm labour decisions}

To further illustrate the results, we use the estimates of the probit models to conduct some simulations. The probabilities of the individuals' off-farm labour participation are calculated under various levels of exogenous variables. First, these simulations illustrate the impacts of variations in the structural variables (human capital characteristics) and variations in instruments of policy (subsidies). Next the sensitivity analysis is conducted to quantify the impact of the new CAP regime.

For the simulations, we consider an average cereal farm which receives no subsidies. We assume that the product price is equal to one hundred francs per quintal. The other continuous variables are taken to the sample mean and the dummy variables are equal to zero. 


\subsection{Change in the human capital variables}

Figure 1 shows the variations of the probability of wife's off-farm participation with respect to age. Two scenarios are considered. In the first one (lower curve) the wife has no highschool general education. In the second case (upper curve) we suppose that the wife has at least a high school diploma.

Figure 1. Impact of the wife's age on her probability of off-farm labour market participation

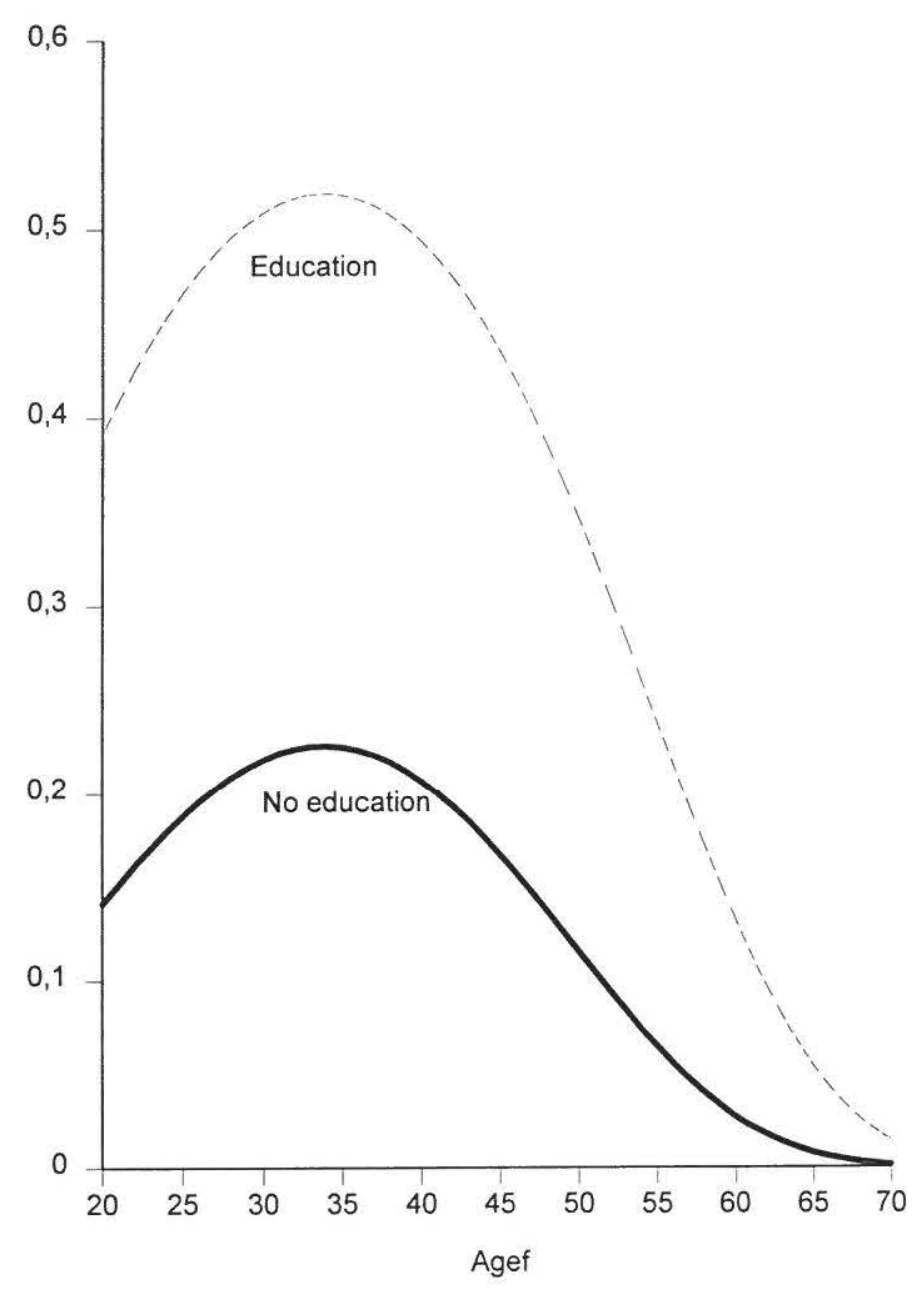

The shape of both curves is explained by the quadratic life cycle effect outlined earlier: for wives older than 34, an additional year of age has a positive but diminishing effect on the probability of off-farm labour participation. Figure 1 proves the strong positive effect of the wife's general education. Whatever the age, with at least a high school diploma the probability of the wife's participation in off-farm labour is more than twice as high as the probability of wives who have no general education. For instance, if we assume that the wife is 30 years old and has no general education, the probability of off-farm participation equals $21.82 \%$. If the wife has a 
general education diploma the probability is equal to $50.90 \%$ : the education induces about a $133 \%$ increase in the wife's off-farm participation.

The same analysis is conducted to study the effect of the husband's age on his probability of off-farm participation. Figure 2 shows how the probability changes as the husband's age increases.

Figure 2. Impact of the husband's age on his probability of off-farm labour market participation

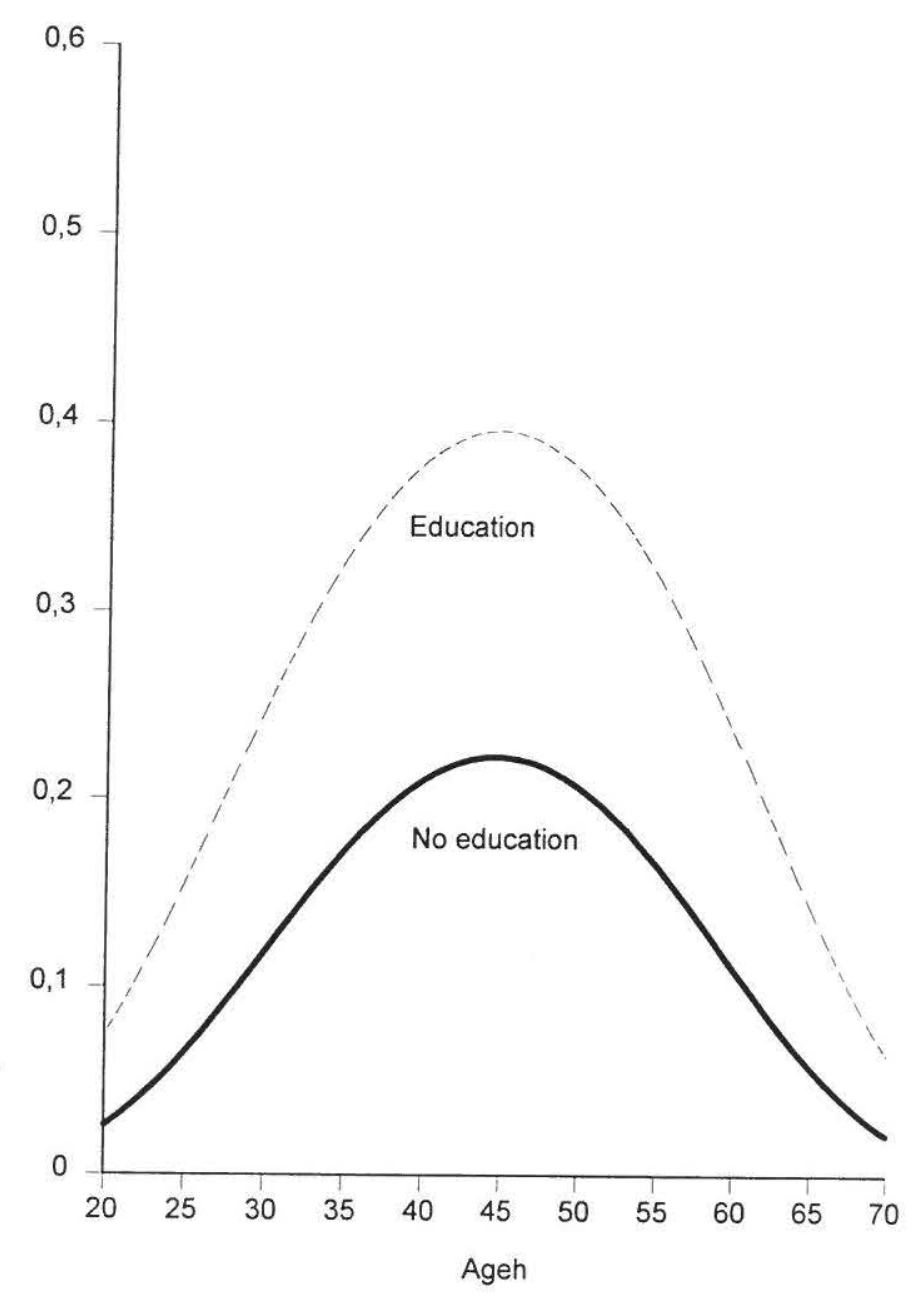

The highest value for the probability appears for an older age than for the wife. As in the first case, general education causes an outward shift of the curve. However this shift is not so important as it was for the wife. For instance if we assume that the husband is 30 years old and has no general education, the probability of off-farm participation equals $11.90 \%$. If he has a general education diploma the probability is in this case $24.85 \%$. The education induces about a $110 \%$ increase of the husband's probability of off-farm participation. 


\subsection{Change in nonfarm income}

We consider that the change in nonfarm income is due to an increase in subsidies received by the farm. Increase in subsidies can be a means to maintain activity on farm and to avoid depopulation of the country. Indeed, aids to farms can be intended to promote forms of diversification activities on farm or to compensate for difficult farming conditions in less favoured areas. We calculate the amount of subsidies that the farm household should receive in the order that the wife's probability of off farm participation does not increase. The amount depends in particular on the wife's age and on the department where the farm is located.

\subsubsection{Link between nonfarm income and the wife's age}

The link between the wife's age and the amount of nonfarm income is illustrated with the figure 3 .

Figure 3. Frontier of participation in off-farm labour : the age effect

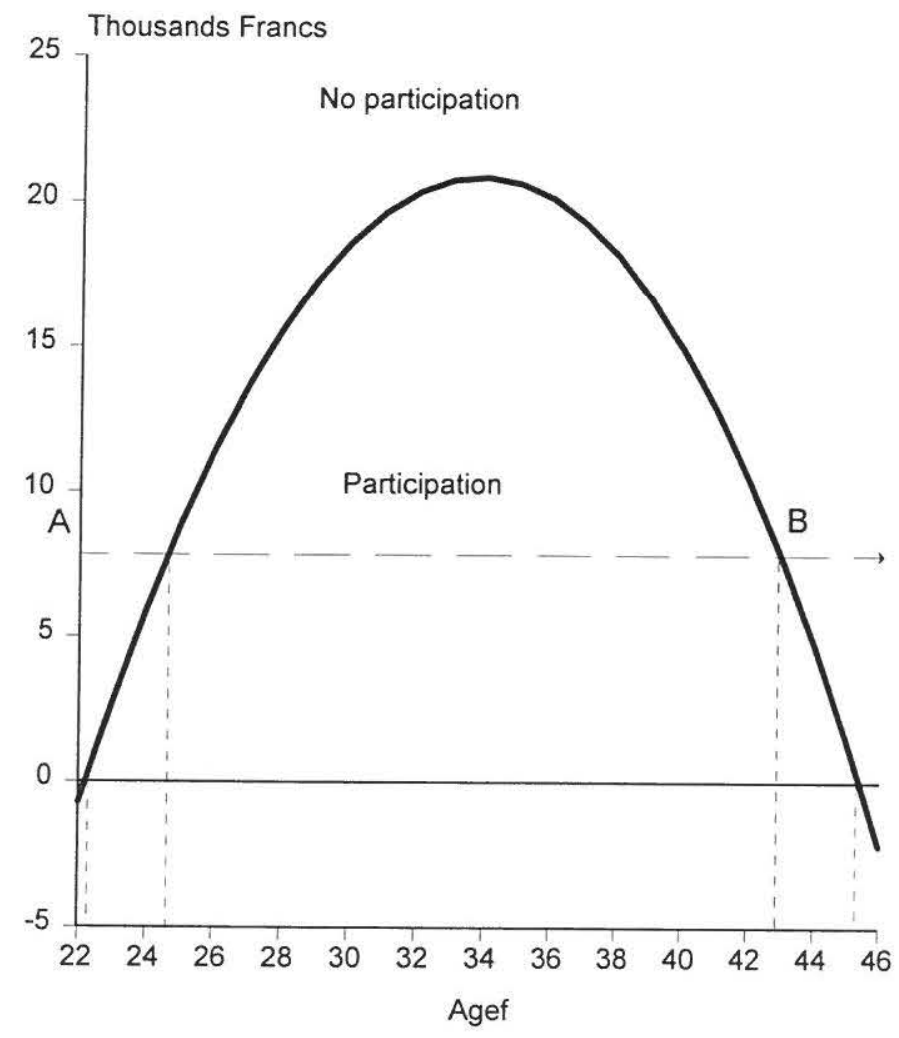


The concave curve, drawn with respect to the wife's age, defines the amount of subsidies that the farm should receive so that the wife's probability of off-farm participation would be equal to 0.5 . Above the curve, the probability is lower than 0.5 (the probability is decreasing with the level of subsidies). Below the curve, the probability is greater than 0.5 . Since we admit that the event of off-farm participation is predicted to occur if the probability of off-farm participation is greater than or equal to 0.5 (Judge 1988 p.794), above (below) the curve and the wife is predicted not to work (to work) off farm.

The horizontal line $(A, B)$ measures the amount of the compensatory payment for the reduced price that the farm would receive under the CAP reform ${ }^{7}$. We assume that before the CAP reform the farm has no subsidies. Hence, the wives who are between 23 and 46 years old are predicted to work off farm. The intersecting points with the horizontal line and the curve define the ages for which the wives' behaviour is not affected by the receipt of subsidies: they still are working off farm. Indeed for wives who are between 26 and 42 years old, the amount planned in the CAP reform is not sufficient to keep them off the off-farm labour market. For instance if the wife is 36 years old compensatory payments would need to be twice as high as those given under the CAP.

For the wives who are under 23 years old, the amount of compensatory payments planned in the CAP reform is sufficient to keep them off the off-farm labour market. It is worth noting that the wives' behaviour who are older than 46 does not vary with or without compensation. They do not participate in the off-farm labour market.

\subsubsection{Link between nonfarm income and the location of the farm}

One potential policy to reduce the population decline in some rural areas might be to raise subsidies for such areas. The amount of aids necessary to keep the wives off the off-farm labour market vary by the department i.e. depends on the location of the farm (figure 4).

\footnotetext{
7 We consider an average grain farm (see table 1). Hence the amount of compensatory payments is equal to 10212 francs (i.e. $74 * 30 * 4.6$ ), 4.6 tonnes per hectare used as a reference yield.
} 
Figure 4. Frontier of participation in off-farm labour : the location effect

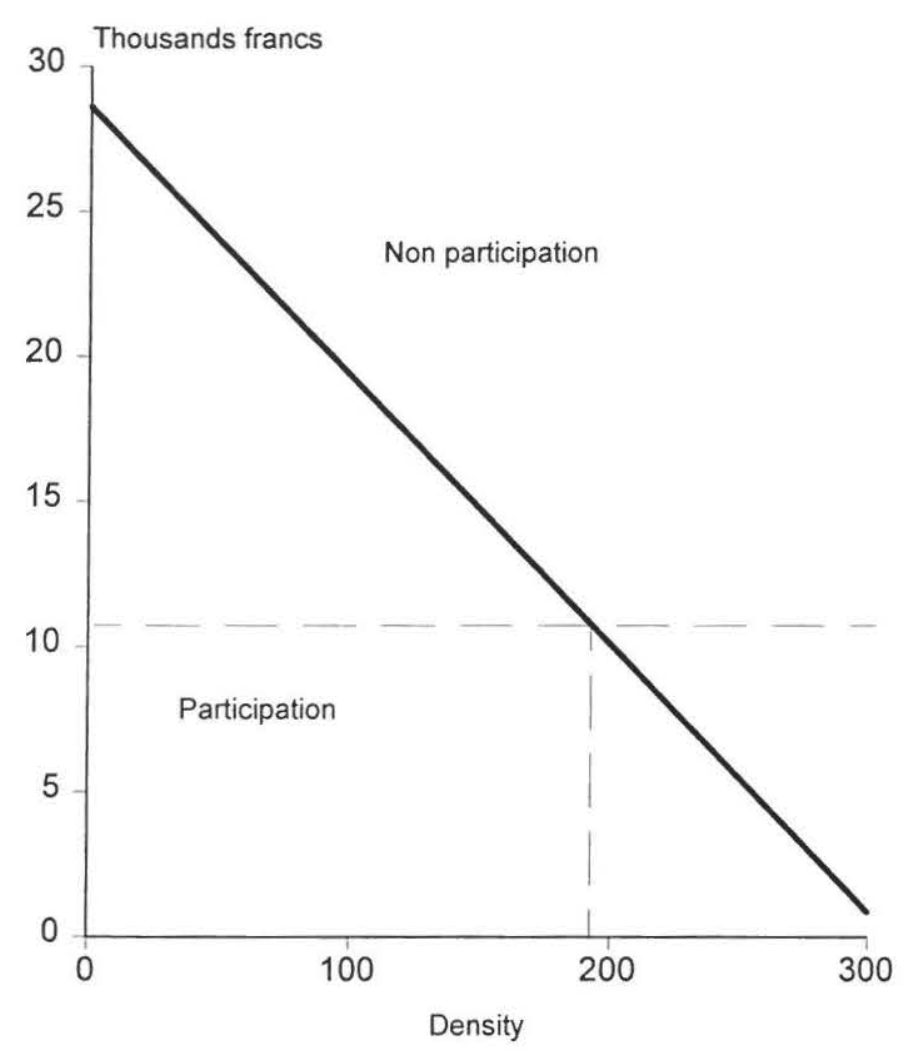

On figure 4, the downward slope line defines the amount of subsidies that the farm should receive in order that the wife's probability of off-farm participation will be equal to 0.5 (we assume that the wife is 30 years old). Above (below) the line the probability is less (greater) than 0.5 and the wife is predicted not to work off farm (to work). As for the figure 5, the horizontal line gives the amount of the compensatory payment for reduced price that the farm will receive under CAP reform. For the departments, which have a density greater than 190, the amount of compensatory payments planned in the CAP reform is sufficient to keep the wives off the offfarm labour market.

\subsection{Effect of the CAP reform on wife's participation}

The predicted effect of each instrument of the CAP reform is confirmed in the wife's participation equation ${ }^{8}$.

\footnotetext{
8 In the simulations of the effect of the CAP reform we do not consider the husband's behaviour and the decision to use hired labour since in both probit equations the coefficient of the product price is not significant.
} 
We consider a farm under CAP reform i.e. which faces a $30 \%$ decrease of the product price and sets aside $15 \%$ its acreage and in turn receives compensation. We study the effect of the new levels of the three variables on the decision to work off-farm. For the other continuous variables, we use the sample mean and the dummy variables are equal to zero. We conduct the analysis in the case where the wife has no general education and in the case where the wife has at least a high school diploma. The impact on the probability of the wife's participation in the offfarm labour market is shown by the figure 5 .

Figure 5. The CAP and the education effect on the wife's probability of off-farm labour participation

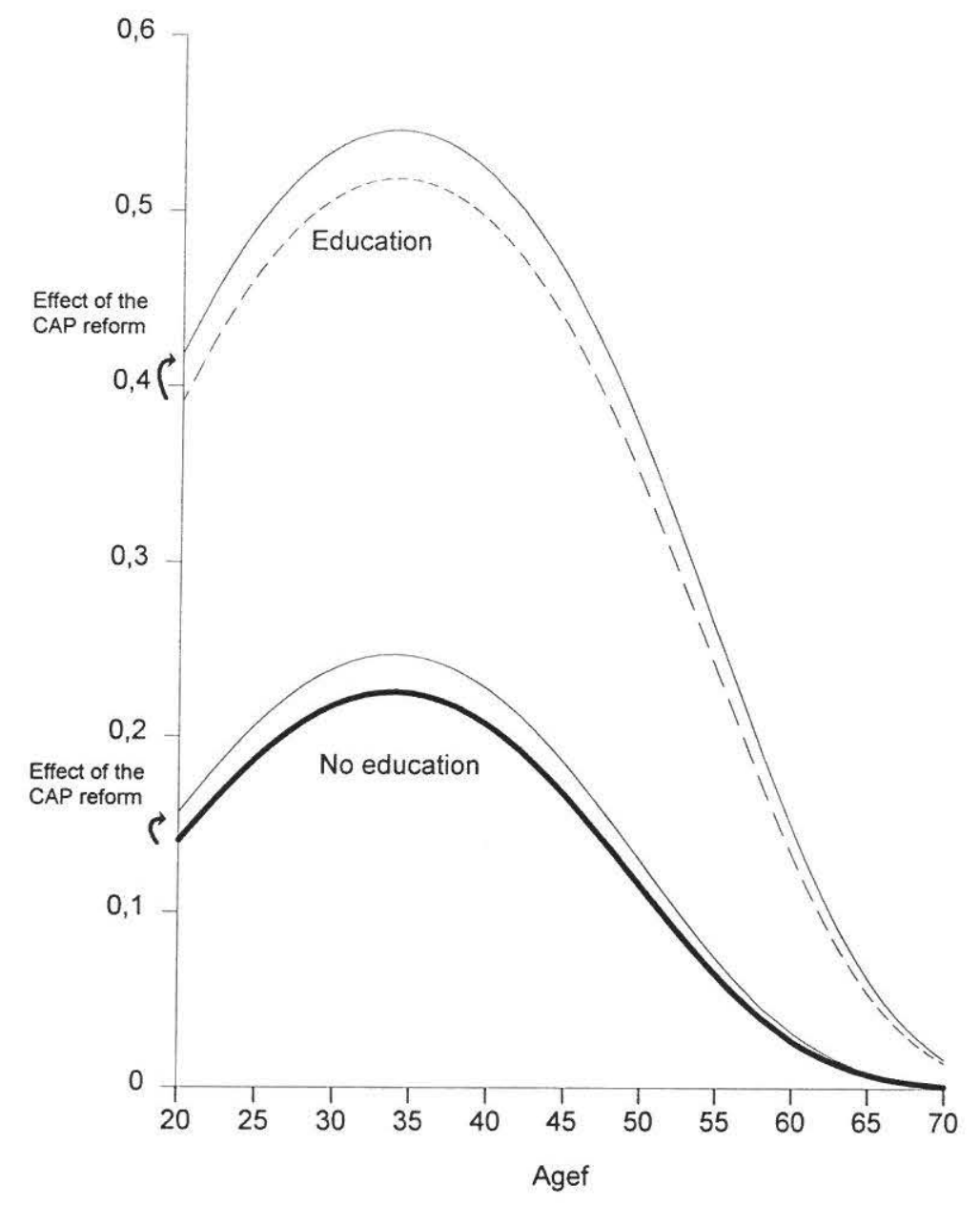

As we predicted from the theoretical analysis, the effects of the price cuts, set-aside and the compensatory payments is positive on the probability of off-farm labour participation. In both cases (with or without general education) there is a vertical shift of the curve which describes the variations of the probability of off-farm participation. However, the probability increases by less than the shift induced by the variation in the general education. For instance, we assume that the wife is 30 years old. When she has no general education, the probability of off-farm participation 
increases from $21.82 \%$ to $23.93 \%$ (around a $10 \%$ increase). If the wife has a general education diploma, the CAP reform induces about a $5 \%$ increase in the wife's off-farm participation (from $50.90 \%$ to $53.67 \%)$.

The difference between these figures and the previous results indicates that while the CAP reform will increase wives' off-farm participation, education and age have a greater positive effect. Furthermore, these simulations show that the impact of the CAP reform on off-farm labour participation is higher for wives who do not have a high school diploma than for those who do.

\section{Conclusion}

This paper analyses the off-farm labour supply and hired labour demand of farm households in a theoretical context of a household model behaviour; Furthermore, the paper has attempted to address the empirical effect of the CAP reform on labour decisions of French agricultural households. Indeed, changes caused by this support shift may induce a reallocation between work activities for the members of the household. First, the firm-household model has been used to derive the rule concerning the off-farm labour market participation and the decision of employing hired labour on farm. Comparative static analysis in a simplified model allows us to predict how the probability of off-farm participation. The study focuses mainly on the decision to work off farm. Both the decrease in the product price and the new set aside requirements induce a decrease in the reservation wage and hence an increase in the probability of off-farm labour participation. On the other hand, receipt of compensatory payments has a positive effect on the reservation wage, i.e. a negative effect on the probability of the off-farm labour participation. Probit models allow to search for the factors affecting the probability of working off farm for the wife and the husband and the probability of using hired labour on the farm. Empirical results provide information on relationship between family labour and hired labour and support the interest of a joint analysis of labour decisions of the agricultural households. Furthermore, parameters are used to quantify the effects of the variation in the product price, the farm size and subsidies. For the wives, the effect of the three instruments are significant (unlike the husband) and positive on the probability of off-farm labour participation. The findings suggest that increases in wives' human capital (for instance, in general education and in age) will have the greatest effect on the probability on off-farm labour participation.

Several aspects of the analysis presented here deserve further consideration. First, the empirical analysis allows an examination of interrelationships between family labour and hired 
labour. In particular, hired labour was shown to be a substitute for female labour. This result was derived under the assumption that we can define a consistent aggregate of hired labour by assimilating seasonal and regular hired labour. However previous studies (Gunter and Vasavada, 1988) found that substitution relationships between family labour and these two types of hired labour are different. Hence the disaggregation of hired labour is a possible improvement. Furthermore, we might expect that variations in exogenous variables would induce different effects on these both types of labours. Second, an alternative empirical specification would be to consider explicitly in a simultaneous model (as a logit multinomial) the labour regimes (self sufficient, sellers, employers) which can appear for a farm household. This estimation procedure which is heavier in the interpretation of the results, will allow to anticipate how the different categories of households will respond to variations in the exogenous variables. For instance, such an analysis could be used to compare the effect of the CAP reform on off-farm labour for agricultural households in which the farm wife is not currently employed off-farm to agricultural households where the farm wife is employed off-farm. 
Annex. Data definitions

\begin{tabular}{|c|c|c|}
\hline Variables & Units & Means \\
\hline $\begin{array}{l}\text { Human capital } \\
\text { Agef } \\
\text { i's age }\end{array}$ & Years & 46.89 \\
\hline $\begin{array}{l}\text { Dumeducf } \\
\text { equals } 1 \text { if the wife has a secondary school leaving, } 0 \text { otherwise }\end{array}$ & $\%$ & 19.24 \\
\hline $\begin{array}{l}\text { Dumeduch } \\
\text { equals } 1 \text { if the farm operator has a secondary school leaving, } 0 \text { otherwise }\end{array}$ & $\%$ & 10.21 \\
\hline $\begin{array}{l}\text { Dumagrf } \\
\text { equals } 1 \text { if the wife has an agricultural high school diploma, } 0 \text { otherwise }\end{array}$ & $\%$ & 0.98 \\
\hline $\begin{array}{l}\text { Dumagrh } \\
\text { equals } 1 \text { if the farm operator has an agricultural high school diploma, } 0 \text { otherwise }\end{array}$ & $\%$ & 9.22 \\
\hline $\begin{array}{l}\text { Exp } \\
\text { farm experience of the operator }\end{array}$ & Years & 21.63 \\
\hline $\begin{array}{l}\text { Dumpermf } \\
\text { equals } 1 \text { if the wife has followed agricultural training since } 1980,0 \text { otherwise }\end{array}$ & $\%$ & 7.38 \\
\hline $\begin{array}{l}\text { Dumpermh } \\
\text { equals } 1 \text { if the farm operator has followed agricultural training since 1980, } 0 \text { otherwise } \\
\text { Household characteristics }\end{array}$ & $\%$ & 14.43 \\
\hline $\begin{array}{l}\text { Less } 6 \\
\text { number of children under six }\end{array}$ & nu & 0.18 \\
\hline $\begin{array}{l}\text { Kids } 612 \\
\text { number of children between six and twelve }\end{array}$ & nu & 0.34 \\
\hline $\begin{array}{l}\text { Old12 } \\
\text { number of children over twelve }\end{array}$ & nu & 0.81 \\
\hline $\begin{array}{l}\text { Nbind } \\
\text { total number of family members living on farm } \\
\text { Farm characteristics }\end{array}$ & nu & 3.88 \\
\hline $\begin{array}{l}\text { Size } \\
\text { farm size in hectares }\end{array}$ & ha & 74.08 \\
\hline $\begin{array}{l}\text { Price } \\
\text { price of the product }\end{array}$ & Fr./q & 70.21 \\
\hline $\begin{array}{l}\text { Dumgaec } \\
\text { equals } 1 \text { if the farm is a partnership, } 0 \text { otherwise }\end{array}$ & $\%$ & 12.78 \\
\hline $\begin{array}{l}\text { Dummicro } \\
\text { equals } 1 \text { if the farm uses a computer, } 0 \text { otherwise }\end{array}$ & $\%$ & 11.93 \\
\hline $\begin{array}{l}\text { Dumdivers } \\
\text { equals } 1 \text { if there are diversification activities on farm, } 0 \text { otherwise }\end{array}$ & $\%$ & 21.14 \\
\hline $\begin{array}{l}\text { Dumtourism } \\
\text { equals } 1 \text { if there are tourism activities on farm, } 0 \text { otherwise }\end{array}$ & $\%$ & 1.51 \\
\hline $\begin{array}{l}\text { Dumdev } \\
\text { equals } 1 \text { if structural improvements were made on farm, } 0 \text { otherwise }\end{array}$ & $\%$ & 10.01 \\
\hline $\begin{array}{l}\text { Dumtract } \\
\text { equals } 1 \text { if the farm uses a tractor, } 0 \text { otherwise } \\
\text { Exogenous income }\end{array}$ & $\%$ & 63.84 \\
\hline $\begin{array}{l}\text { Subven } \\
\text { agricultural subsidies } \\
\text { Location characteristics }\end{array}$ & $\mathrm{F}$ & 7175.19 \\
\hline $\begin{array}{l}\text { Density } \\
\text { number of inhabitants per square kilometer in the department } \\
\text { Averoff } \\
\text { average number of wives (husbands) who work off farm in the department }\end{array}$ & $\begin{array}{c}\mathrm{HA} / \mathrm{K} \\
\mathrm{nu}\end{array}$ & $\begin{array}{l}107.97 \\
12.13 \\
(8.12)\end{array}$ \\
\hline
\end{tabular}




\section{References}

Benjamin C., 1993, L'affectation du travail dans les exploitations agricoles : approche microéconomique et application sur données françaises. Thèse de l'université de Paris I

Diewert W.E, 1974, Applications of duality theory. In M.D Intriligator and D.A Kendrick (eds) Frontiers of quantitative economics vol. II, North Holland: Elsevier, 106-206.

Gasson R., 1988, Farm Diversification and Rural Development, Journal of Agricultural Economics, 39, pp. 175-182.

Gunter L., Vasavada U., 1988, Dynamic labour demand schedules for US agriculture, Applied Economics, 20 pp- 803-812.

Huffman W. E., Lange M. D., 1989, Off-Farm Work Decisions of Husbands and Wives: Joint Decision Making, Review of Economics and Statistics, 71, pp. 471-480.

Huffman W. E., 1991, Agricultural Households Models: Survey and Critique. In, Lass A. O., Findeis 1. J. and Hallberg M. C. eds., Multiple Job-Holding Among Farm Families, Iowa State University Press, pp. 79-111.

Judge G. G., Griffiths W. E., Hill R. C., Lutkepohl H., Lee T. C., 1985, The Theory and Practice of Econometrics. 2nd ed., Wiley, New-York.

Lass A. D., Findeis L. J., Hallberg M. C., 1991, Factors Affecting the Supply of Off-Farm Labor: A Review of Empirical Evidence. In, Lass A. O., Findeis 1. J. and Hallberg M. C. eds., Multiple Job-Holding Among Farm Families, Iowa State University Press, pp. 239-62.

Lopez R. E., 1984, Estimating Labor Supply and Production Decisions of Self-Employed Farm Producers, European Economic Review, 24, pp. 61-82.

Nakajima C., 1986, Subjective Equilibrium Theory of the Farm. Developments in Agricultural Economics, Elsevier, Amsterdam.

The arkleton trust, (1991). Farm family pluriactivity in Western Europe. Arkleton Trust, research Ltd United-Kingdom. 